УДК 821.111-31.09

DOI https://doi.org/10.26661/2414-9594-2021-1-36

\title{
СИМВОЛІКА ОБРАЗІВ ВОДНОЇ СТИХІЇ В РОМАНІ В. ГОЛДІНГА «СПАДКОЄМЦІ»
}

\author{
Шаповал О. Г. \\ кандидат філологічних наук, \\ старший викладач кафедри германських мов $і$ зарубіжної літератури \\ Кам'янець-Подільський національний університет імені Івана Огієнка \\ вул. Огієнка, 61, Кам'янець-Подільський, Хмельницька область, Україна \\ orcid.org/0000-0003-0191-3154 \\ shapoval@kpnu.edu.ua
}

Ключові слова: образ, символ, притча, міф, архетип.
Стаття присвячена аналізу образів водної стихії в романі В. Голдінга «Спадкоємці». Вказано на жанрову своєрідність твору, яка грунтується на досягненні гармонійного балансу фабульного й ідейного рівнів притчі, де на рівні фабули роман являє собою трагічну історію про знищення групи неандертальців, а на глибинному філософському рівні втілює ідею діалектики прогресу, за який людству доводиться розплачуватися моральними втратами. 3'ясовано, що образ води, як один iз найпоширеніших архетипних об'єктів словесно-художньої творчості, набуває особливої ваги у творах притчового та міфологічного характеру, де імпліцитно реалізується вся множина його символічних значень. У статті проаналізовано символічні образи снігу, криги, талої води, озера, болота, ріки, водоспаду і сліз, що репрезентують водну стихію в романі «Спадкоємці». Доведено, що ситуація зміни епох символічно позначається в тексті роману зміною пір року, приходом весни, таненням льоду і снігу. Визначено, що вода символізує народження нової епохи, а лід - того світу, що залишається позаду, застиглих, нерозвинутих потенцій людства і людської свідомості. Дане символічне навантаження образу дозволило тлумачити жах, який у неандертальців викликає вода, як страх перед майбутнім, чужим їм новим часом. Доведено, що образ ріки в тексті роману співвідноситься з міфологічними образами «кордону», «світового шляху», «стрижня всесвіту», а також набуває семантики «ріки мертвих». Охарактеризовано образ водоспаду в його зв'язку з образами «нових людей» та біблійним міфом про гріхопадіння та Втрачений рай. Доведено, що в романі «Спадкоємці» символіка водної стихії має амбівалентний характер. Вода виступає силою водночас життєдайною і смертоносною, рятівною і ворожою, постійно змінює свій стан - від свіжої і прозорої до каламутної, темної, брудної. Дослідження показало, що символіка образів водної стихії в романі «Спадкоємці» формується на основі поєднання архетипних, міфологічних та індивідуально-авторських уявлень і дозволяе розкрити додаткові зв'язки і значення, імпліцитно закладені в тексті твору. 


\title{
THE SYMBOLIC MEANING OF THE WATER IMAGES IN THE WILLIAM GOLDING'S “THE INHERITORS"
}

\author{
Shapoval O. H. \\ Candidate of Philological Sciences, \\ Senior Lecturer at the Department of the Germanic Languages and Foreign Literature \\ Kamienets-Podilskyi Ivan Ohiienko National University \\ Ohiienko str., 61, Kamienets-Podilskyi, Khmelnytskyi region, Ukraine \\ orcid.org/0000-0003-0191-3154 \\ shapoval@kpnu.edu.ua
}

Key words: image, symbol, parable, myth, archetype.
The article deals with the analysis of the water images in the W. Golding's "The Inheritors". The novel's genre originality based on a harmonious balance of plot and ideological levels of the parable is pointed out. At the plot level the novel tells a tragic story about the destruction of a group of Neanderthals, and at a deep philosophical level embodies the idea of progress dialectics. It was emphasized that the water image, as one of the most common archetypal objects of verbal and artistic creativity, acquires special significance in parables and myths, where the whole set of its symbolic meanings is implicitly realized. Symbolic water images of snow, ice, melt water, lake, marsh, river, waterfall and tears are analyzed in the article. It is proved that the changing of epochs symbolically reflects in the changing of seasons, the arrival of spring, the melting of ice and snow. It is determined that water symbolizes the birth of a new era, and ice - the world of the past, the frozen, undeveloped potentials of humanity and human consciousness. This symbolic meaning allowed us to interpret the horror that water causes to Neanderthals, as fear of the future. It is proved that the image of the river in "The Inheritors" correlates with the mythological images of the "border", "world path", "core of the universe", and also acquires the semantics of the "river of the dead". The connection of the waterfall image with the images of "new people" and the biblical myth of the Fall and Paradise Lost is characterized in the article. It is proved that in "The Inheritors" the symbolism of the water image has an ambivalent character. Water is represented as a life-giving and deadly, saving and hostile force. It is constantly changing - from fresh and transparent to muddy, dark, dirty. It is concluded that the symbolism of the water images is formed on the basis of a combination of archetypal, mythological representations and author's ideas, that allows to reveal additional connections and meanings implicitly embedded in the text of the novel.
Постановка проблеми. Проблема тотальної невизначеності, епістемологічної й аксіологічної непевності, хисткості всіх засад, з якою людина зіткнулася у XX ст., визначила експеримен-

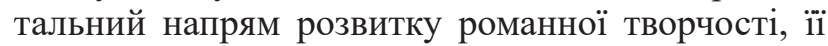
тяжіння до умовності, інакомовлення, філософічності. Одним із найпродуктивніших шляхів оновлення романного жанру у другій половині $\mathrm{XX}$ ст. стали різноманітні форми художнього синтезування, що привело до появи таких жанрових форм, як «роман-притча», «роман-міф», «роман-алегорія» тощо. Таким романам властиві високий ступінь узагальнення, універсальність і прозорість сенсу, діалогічна багатозначність і алегоричність. Особливу роль у створенні бага- тозначного інакомовлення відіграє символічна образність. У літературі та мистецтві символ розглядається як універсальна категорія естетики, як «знак, наділений усією органічністю міфу i невичерпною багатозначністю образу» [1, с. 826]. Згідно 3 таким тлумаченням, будь-який символ $є$ образом. I навпаки - будь-який образ $\epsilon$, тією чи іншою мірою, символом, оскільки предметність образу i глибинність його сенсу становлять у структурі символу нерозривну єдність. Змістовність символу безпосередньо залежить від його багатозначності, наприклад його співвіднесення зі стрижневими ідеями світової цілісності, 3 повнотою людського, а ширше - космічного універсуму. Структура ж символу спрямована на те, щоб 
«занурити кожну частку явища у стихію «першопричин» буття і дати через це явище цілісний образ світу» [1, с. 826-827]. Отже, символічна образність у творах притчового та міфологічного характеру найповніше реалізує всю множину своїх імпліцитних значень, формує унікальноавторську картину світу.

Художні пошуки британського письменника Вільяма Голдінга завжди тяжіли до жанрового синтезу, використання умовних, притчових форм i відіграли важливу роль у формуванні історико-літературного процесу другої половини XX ст. Символічна образність творів В. Голдінга досліджувалась переважно на матеріалі найвідоміших романів письменника («Володар мух» $\mathrm{i}$ «Шпиль») у працях Н. Дікен-Фуллера, С. Вайнтрауба, Д. Андерсона, С. Павличко, Л. Мірошниченко, Ю. Шаніної, Д. Єфімової та інших. Наприклад, С. Павличко у книзі «Лабіринти мислення» центральним образом «Володаря мух» називає темряву, а ідейним лейтмотивом визначає «здоровий глузд» (common sense), який поступово втрачають діти на острові [2, с. 46]. Образ вогню в романі «Володар мух» досліджувався в наших попередніх розвідках [3], вітчизняна дослідниця Л. Мірошниченко також розглядала цей образ в контексті Гераклітової теорії першостихій [4]. Концепти-архетипи першостихій у творчості В. Голдінга стали предметом дисертаційного дослідження сучасної мовознавиці О. Гринько [5].

Проте роман «Спадкоємці» (“The Inheritors", 1955 р.), який сам В. Голдінг називав найкращим своїм твором [6, с. 481], досі залишається на периферії голдінгознавства і найчастіше досліджується в контексті загального аналізу ранньої творчості автора. Увагу дослідників привертали проблематика і жанрова своєрідність роману (Дж. Бейкер, С. Вайнтрауб, С. Кошелєв, М. Кечерукова), зв’язок із літературною традицією (А. Нямцу, О. Литвинюк), а вивчення поетики цього твору, зокрема символічної образності, має фрагментарний характер. Зауважимо, що вивчення образів водної стихії здебільшого відбувалось у контексті загального аналізу символіки роману і не було предметом окремого дослідження. Так, у розвідці, присвяченій символіці і проблематиці роману «Спадкоємці», російська дослідниця М. Кечерукова вказує, що «вода займає особливе місце в символіці роману» [7, с. 264], проте зосереджує свою увагу лише на образі водоспаду, слушно зауважує, що його «алегоричне значення дає ключ до розуміння філософського задуму всього роману» [7, с. 264]. О. Гринько розглядає функціонування символів у романі «Спадкоємці» та зазначає лише два репрезентанти символіки водної стихї в романі: fall (waterfall) (водоспад) та weed-tails (хвостаті трави) [8], залишає поза увагою інші образи.
Мета статті - визначити образи, які представляють водну стихію в романі «Спадкоємці», розкрити їхнє символічне навантаження та дослідити шляхи реалізації символічних значень образів води в тексті роману. Для досягнення поставленої мети в дослідженні використовувались елементи структурно-функціонального методу, міфокритики, комплексного аналізу художнього тексту.

Виклад основного матеріалу. Роман «Спадкоємці» багато в чому розвиває і поглиблює тему співвідношення добра i зла у природі людини i пов'язану 3 нею проблему людини і цивілізації, заявлену «Володарем мух», що дозволило дослідникам навіть розглядати їх як романи, що утворюють пару [9, с. 43]. Крім того, тут автор продовжує вдосконалювати притчову манеру освоєння дійсності, досягає гармонійного балансу фабульного й ідейного рівнів притчі. На рівні фабули роман являє собою трагічну історію про знищення групи неандертальців, а на глибинному філософському рівні втілює ідею діалектики прогресу, за який людству доводиться розплачуватися багатьма моральними втратами [10, с. 198]. Образи-символи водної стихії постають важливим компонентом розкриття ідейно-філософської концепції автора.

Уже на першій сторінці роману неандертальців зупиняє «оніксова болотна вода» [11, с. 11] (тут і далі переклад 3 англ. наш - O. Ш.), з якої зникла колода, яка завжди допомагала племені перейти на інший берег. Болотна вода на фабульному рівні постає простою перешкодою на шляху. Опис ситуації іi подолання дозволяє авторові розповісти про плем'я, розкрити своєрідність спілкування, стосунків, поведінки кожного 3 неандертальців. Проте лексика, яку використовує В. Голдінг для іiі характеристики: «оніксова», «жахлива», «спляча», «глибока», той жах, який перед нею відчувають неандертальці, нарешті, падіння у води болота старійшини Мала наділяють цей образ символікою небезпеки, страху, ірраціонального, що буде лише посилюватись із плином розповіді й віддзеркалиться у фіналі твору в образі «темної смуги», що немає кінця. У фіналі твору водна стихія представлена образом великого озера, яким пливе парусний човен «нових людей», що нарешті втекли від «лісових дияволів» - неандертальців. На перший погляд образ озера - «безмежний простір», «сяюча вода» символізує прекрасне майбутнє, яке чекає «нових людей», і протиставляється темряві болота, яка залишилась позаду. «Вітер попутний, човен слухається керма, а навколо водна широчінь - чого ж ще бажати людині?» [11, с. 224] - думає Туамі. Але те, що «нові люди» пережили на острові, змінило їх, адже «перетягнувши човна $<\ldots>$ від лісу до витоку водоспаду, вони ніби опинились на новій висоті не тільки над земною поверхнею, 
а й над власним досвідом і відчуттями. Світ, у серцевині якого так повільно просувався човен, огортала темрява серед світла, і був він брудний, загиджений, без проблиску надії» [11, с. 225]. Образи водної стихії на початку і у фіналі роману замикають композицію твору у своєрідне коло: темрява болота, що втілює ірраціональний страх неандертальців, перетворюється на темну смугу, що символізує темряву людської душі, яка ставить під сумнів «блискуче» майбутнє «нових людей»: «Туамі пильно вдивлявся вперед, у безкрайню широчінь попереду вітрила, виглядаючи, що ж там, на іншому кінці озера, але воно було таке довге і вода в ньому виблискувала так сліпуче, що йому не вдалося розгледіти, чи $є$ взагалі кінець у цієї темної смуги» [11, с. 233].

Значущою виявляється реалізація символічних значень образів водної стихії і на хронотопному рівні роману-притчі. Досліджуючи специфіку творчого методу В. Голдінга, вітчизняні літературознавці А. Нямцу й О. Литвинюк зазначають, що письменник «не ставив перед собою мету створити повнокровну картину часу» [12, с. 100], адже «характер історичного процесу змінюється не настільки принципово, щоб позитивно вплинути на природу людини. Навіть більше, у «Спадкоємцях», де романіст несподівано обрав предметом зображення саме час, зміну епох, він спробував довести, що будь-який розвиток у суспільстві несе в собі моральні втрати» [12, с. 100]. Важливо, що для зображення зміни епох автор безпосередньо використовує образи водної стихіі, символічне навантаження яких формується поєднанням універсальних міфологічних значень і авторського світобачення. Так, у словнику символів Дж. Трессідера вода розглядається як «давній універсальний символ чистоти, родючості і джерело самого життя» [13, с. 42]. Автори енциклопедії «Міфи народів світу» вказують, що «у різних міфологіях вода - першооснова, початковий стан усього сущого, вселенський збіг потенційних можливостей, що передує всім формам і всьому творінню» [14, с. 240]. У романі «Спадкоємці» змальована ситуація загибелі старої цивілізації (неандертальців) і народження нової (homo sapiens), тому семантика образу води як середовища загального зачаття і народження [14, с. 240] стає особливо значущою. Завершується льодовиковий період - епоха неандертальців, що символічно позначується в тексті роману зміною пір року, приходом весни, таненням льоду і снігу, дзюрчанням талої води. Яскравим символом кінця старої епохи стає танення крижаного святилища матері-природи Оа, з лона якої, за віруванням неандертальців, з'явилися земля і люди. Британський структураліст Філіп Редпас трактує ім'я Богині «Оа» як Альфу і Омегу, що міняються місцями
(Oa/Ao) - кінець епохи неандертальців, початок нового періоду в історії людства $[15$, с. 91]. У величних брилах льоду, які своєю формою нагадували жіночі фігури, неандертальці бачили втілення Оа. «Крижані жінки» були не просто берегинями святилища, а й самою першоосновою, що дає життя новому світу: «Печери, де зникали батоги величезних в'юнків, були їхніми («крижаних жінок»- О. Ш.) лонами. Їхні стегна і черева виступали із кручі у височині. Вони нависали так тісно, що небо здавалося меншим за святилище. Тіло спліталося 3 тілом, вони хилилися, гнулися і загострені їхні голови виблискували під місячним сяйвом. Лок побачив, що лона їхні подібні до печер, блакитних і наповнених жахом. Вони відділялися від поверхні скелі, і в'юнок був водою, яка сочилася між скелею і льодом» [11, с. 79-80].

Отже, тала вода стає символом епохи, що народжується, лід - того світу, що залишається позаду, застиглих, нерозвинутих потенцій людства і людської свідомості. У цьому значенні символіка «замороженої води» перегукується із символічним навантаженням імені протагоніста роману неандертальця Лока (англ. lock - «замок»; «замикати», «стискати», «блокувати»). Жахливий звук обвалу гірської криги - завершення існування святилища богині $\mathrm{Oa}$ - символічно супроводжує трагічну картину його смерті. Дане символічне навантаження образу дозволяє розглядати жах, який неандертальці відчувають перед водою, як страх перед майбутнім, чужим їм новим часом, а не просто як природний страх перед могутньою стихією. Так, на початку роману, коли неандертальці ще не відчули жодних змін, необхідність намочити хоча би ноги викликає загальне співчуття: «Ха зітхнув і $з$ побоюванням ступив однією ногою у воду. Коли люди побачили це, вони співчутливо застогнали» $[11$, с. 13]. У зіткненнях 3 «новими людьми» і спробах врятувати залишки свого племені вони вимушені долати природний страх, і спочатку Лок «осмілився ступити у воду» $[11$, с. 95], а потім і Фа, рятуючись від переслідування, ховається у воді, тому що «краще вже вода, ніж нові люди» [11, с. 199].

$\mathrm{He}$ можемо погодитись із зауваженням А. Нямцу й О. Литвинюк, що в романі «часові характеристики $<\ldots>$ настільки акцентовані, що знижують роль просторових, також значущих у своїй мірі» [12, с. 162-163]. Зазначимо, що символіка образів водної стихії розгортається як у часовому, так і у просторовому планах художньої структури роману «Спадкоємці», утворює єдність притчового хронотопу. Зміна епох, рух у майбутнє зафіксовані й просторовим переміщенням. Обидва племені здійснюють перехід: вони приходять (припливають) від моря до ріки і водоспаду в пошуках їжі та безпеки. Отже, образи води водно- 
час презентують характеристики часу і простору: «море» («солона вода») - минуле, місце зимової стоянки обох племен, яке постає лише у спогадах Лока і Туамі; «ріка» - теперішнє, місце, де відбуваються події; «озеро» - майбутнє, недоступне неандертальцям.

Зустріч двох племен відбувається на берегах могутньої ріки, образ якої виступає не лише яскравим елементом прадавнього ландшафту, а й несе в собі множину символічних змістів, актуалізованих притчовим наративом. Зокрема, із цим образом пов'язане відчуття плину часу, його історичної зміни, адже ріка «котить свої води з минулого через сьогодення в майбутнє, відносячи нас у своїй течії» [16, с. 130-131]. Ріка, тобто вода, що тече, рухається, вода-потік, що має певну форму (русло), постає буквальним матеріальним утіленням ідеї руху, мінливості. У просторі роману ріка відділяє неандертальців від острова, на якому отаборились «нові люди», відповідно актуалізує символічне значення образу води-ріки як кордону між двома світами (минулого/майбутнього, раціонального/ірраціонального, гріховного/безневинного). Перехід неандертальцями річки-кордону має глибоке символічне значення. Він не лише фіксує черговий етап розвитку дологічної свідомості, а й надає неандертальцям «нового статусу», наближує їх до світу «нових людей». Подолання водної перешкоди стає важливим елементом у моделюванні притчової опозиції двох племен. На відміну від неандертальців, «нові люди» - умілі мореплавці, здатні на своїх човнах долати значні відстані. Рух їхніх вітрильних човнів проти течії річки й озера символічно вказує на відхід від природних законів, на бажання підкорити і підпорядкувати природу.

Події основної частини роману зображуються такими, якими їх сприймає Лок, останній i3 племені «людей»-неандертальців. Розвиток свідомості Лока від примітивного стану до перших логічних зіставлень стає художнім центром роману. Переконливо відтворюється автором така характерна риса неандертальської свідомості, як антропоморфізм - приписування властивих людині якостей явищам навколишнього світу, тваринам. Тісне переплетення життя неандертальців із життям природи, єдність їхнього ритму, підкреслюється використанням спільної мови для явищ природи і подій власного життя. У світі Лока вода може спати і не спати $[11$, с. 8], чекати і йти $[11$, с. 28], жадібно щось поглинати [11, с. 37], підступно ховатися [11, с. 68] тощо. Ріка також «розмовляє», має свій «голос». Така міфопоетична ідентифікація ріки й мовлення, що «базується не лише на акустичному ефекті дзюрчання води, але й на образі самого потоку річки і мовлення, послідовного перетікання - розвитку, від початку до кінця, до стану смислової наповненості» [14, с. 863], набуває особливого символічного значення у творі, адже автор значну увагу приділяє процесу розвитку дологічної свідомості й мовлення неандертальців.

У тексті роману образ ріки співвідноситься також із міфологічним образом «світового шляху», «стрижня всесвіту», що пронизує верхній, середній і нижній світи [14, с. 861$]$ : святилище богині Оа, світ людей і потойбічний світ. Адже 3 розвитком трагічних подій образ ріки поступово набуває семантики «ріки мертвих». Падіння в холодну воду стає причиною смерті старійшини племені, Мала. Тікаючи від «нових людей», падає з обриву в річку і гине мисливець Ха, остання жінка племені, Фа, теж гине у водоспаді. Води ріки забирають тіло убитої старої, хранительки вогню. Повільна течія задає особливий ритм сприйняття, подібний до нічного жахіття: «<..> i ось уже перед Локом 3'явилася спина, що встала сторч уздовж хвостатих трав. Потім голова обернулася до нього так само повільно, ніби уві сні, спливла у воді, наблизилася до його обличчя» [11, с. 105].

У романі «Спадкоємці» символіка водної стихіï характеризується явною амбівалентністю: вона виступає водночас життєдайною і смертоносною, рятівною і ворожою силою, постійно змінює свій стан - від свіжої і прозорої до каламутної, темної, брудної. Брудна темна вода, як уособлення душевного хаосу, проникає у внутрішній світ «нової людини», наприклад, Туамі: «я схожий на водойму, <..> невідомий потік наповнює мене, вирує і звихрює пісок із дна, води затемнені <.. >>» [11, с. 227]. Туамі - воїн-митець, який гострить ніж, задумуючи вбивство старійшини Марлана, i водночас створює витвір мистецтва, прикрашаючи його рукоятку. Усвідомлення темряви людської душі, насамперед своєї власної, кардинально змінило Туамі, підвело його до розуміння того, що «у цих водах ні клинок, ні рукоять не мали сенсу» [11, с. 231]. Сдиним важливим почуттям у світі залишилась материнська любов, утілена в образі схилених докупи голови Вівані та крижів маленького «диявола»: «і все навколо знову раптом стало добре, а збаламучений пісок у мозку Туамі покірно ліг на дно водойми» [11, с. 233].

Особливе місце серед образів, які репрезентують водну стихію в романі, займає образ «води, що падає» - водоспаду, символічне значення якого є сутнісним для сприйняття філософського змісту усього твору [7, с. 264]. Уперше образ водоспаду з'являється на початку роману, коли група неандертальців майже дісталася до свого літнього житла. Вроджений страх перед водною стихією змушує їх відчувати жах i благоговіння перед «водою, що падає». Люди спочатку чують «шум, що ніколи не замовкає і проникає всюди» [11, с. 7], 
шум, що «вилущив життя зі слів» [11, с. 12]. Поступово шум переростає в ревіння, інтенсивність якого прямо пов'язана 3 діями «нових людей»: чим жахливіші їхні вчинки, тим голосніше рев води. «Нові люди» представляються неандертальцям «людьми водоспаду» [11, с. 115], їх «народив водоспад» [11, с. 126], на відміну від самих неандертальців, які, за їхніми віруваннями, вийшли із черева богині природи Оа. Коли головний герой куштує алкогольний напій, який уживають «нові люди», водоспад починає ревіти і всередині його голови [11, с. 201].

У своєму еволюційному розвитку неандертальці, на відміну від нових людей, не змогли перейти водоспад. Цей образ, який існує на фабульному рівні як природний об'єкт, на філософсько-ідейному рівні твору набуває символічного значення, пов'язаного із семантикою англійського слова "Fall", яке означає не лише «водоспад», але й «гріхопадіння». Це свідчить про наявність у творі біблійних мотивів, значення яких деякі дослідники розгортають на весь роман, розглядаючи його як авторську «концептуальну схему біблійного міфу» [17, с. 27]. Невинність свідомості неандертальців, які не знайомі зі злом i не здатні перейти водоспад, співвідноситься із християнським сприйняттям Едему. Водночас подорож «нових людей», які зуміли подолати водну перешкоду, тобто вчинили гріхопадіння, розглядається як початок історії людства [17, с. 28]. Однак, на нашу думку, біблійний міф про Втрачений рай не може служити універсальним ключем до інтерпретації роману. Едем «Спадкоємців» так само примарний, як і Едем «Володаря мух», де вже на початку твору райський острів позначається слідами катастрофи.

Ще одним важливим образом для розкриття ідейно-філософської концепції твору, що репрезентує водну стихію в романі, $є$ сльози. У художньому світі В. Голдінга цей образ набуває особливої символічної значущості (згадаємо плач Ральфа у фіналі «Володаря мух»). У романі «Спадкоємці» семантика образу сліз змінюється з рухом оповіді. Спочатку вода, що капає/тече 3 очей, - це сльози радості: «Ліку захлинулася сміхом і замовкла, 3 очей iї капала вода» $[11$, с. 20]. Безтурботний Лок постійно намагається розсмішити людей і вони часто плачуть від сміху, незважаючи на голод i втому. Перші сльози горя з'являються після загибелі Ха: «3 подивом дивився Лок, як вода текла з іiї очей. Вода ця накопичувалася у країв очних западин, а потім великими краплями падала на губи і на нову людинку» [11, с. 69]. Цей опис готує читача до сприйняття сцени в одинадцятому розділі, коли перспектива оповіді різко змінюється, стає гранично об'єктивною. Автор уже не називає героя-неандертальця на ім'я, а говорить про нього як про «руду істоту» і вживає стосовно нього займенник «воно» (“it”). Проте сцена, у якій Лок усвідомлює жахливу долю Ліку, яку з'їли «нові люди», вирізняється високою поетичністю, подібною до опису смерті Саймона у «Володарі мух»: «Тепер в обох очницях замерехтіло світло, два вогники, слабкі, як зірочки, що відбивалися у гранітних кристаликах на гранях скелі. Потім вогники спалахнули, стали чіткішими, просвітліли, заіскрилися й опустилися на нижній край западини. Але ось раптом у повній тиші вогники перетворилися на тонкі півмісяці, що вилились 3 очниць і на зморшкуватих вилицях затремтіли вузькі відблиски. Вогники знову спалахнули, просвічуючи крізь сріблясті завитки бороди. Вони повисли, подовжились донизу, закапали, скочуючись по бороді із завитка на завиток, і скупчилися на нижньому кінці. Відблиски на вилицях тремтіли, коли по ним стікали краплі, а потім усі ці краплі злилися воєдино на кінці бороди і канули у струмінь сріблястих блискіток, що дзвінко застукав по тьмяному листу» $[11$, с. 220]. Передсмертний плач Лока, як і сльози Ральфа у фіналі «Володаря мух», - це сльози за невинністю світосприйняття, якої більше немає, сльози екзистенційного героя, якому відкрилась справжня сутність людини і жорстокого світу, повного зла.

Висновки. Отже, водна стихія в романі «Спадкоємці» представлена символічними образами моря, снігу, криги, талої води, болота, озера, ріки, водоспаду і сліз. Вони виступають важливими кодовими знаками твору, що дозволяють розкрити додаткові зв'язки і значення, імпліцитно закладені в тексті роману. Символічне значення образів водної стихії формується на основі поєднання архетипних та міфологічних уявлень про воду як джерело життя, уособлення жіночої родючої сили, межу, що позначає кардинальні трансформації, початок та кінець існування всього живого. Крім того, актуалізація амбівалентної міфопоетичної семантики дрозгляданого образу не лише формує філософський підтекст роману, але і розкриває своєрідність притчової форми В. Голдінга як автора, який у своїй творчості тяжіє до універсальності, до постановки ключових питань існування світу і людини. Тому вивчення символіки цього образу на матеріалі інших творів письменника виглядає перспективним для розкриття своєрідності авторської картини світу.

\section{ЛІТЕРАТУРА}

1. Аверинцев С. Символ. Краткая литературная энщиклопедия : в 9-и т. / гл. ред. А. Сурков. Москва : Советская энциклопедия, 1962-1978. Т. 6 : Присказка «Советская Россия». 1971. С. 826-831. 
2. Павличко С. Вільям Голдінг і криза раціоналізму. Лабіринти мислення. Інтелектуальний роман сучасної Великобританії. Київ : Наукова думка, 1993. С. 40-58.

3. Шаповал О. Мотив вогню в романі В. Голдінга «Володар мух». Наукові пращі Кам'янецьПодільського державного університету. Філологічні науки. Кам'янець-Подільський : Абетка-НОВА, 2005. Вип. 10. Т. 2. С. 138-143.

4. Мірошниченко Л. Гераклітовий вогонь у романі В. Голдінга «Видима темрява». Мовні $і$ концептуальні картини світу : збірник наукових праць. Київ : КНУ ім. Т. Шевченка, 2011. Вип. 39. С. 80-87.

5. Гринько О. Концепти-архетипи в прозі В. Голдінга : автореф. дис. ... канд. філол. наук: 10.02.04. Одеса : Одес. нац. ун-т ім. І.І. Мечникова, 2014. 20 с.

6. Dick B. The novelist is a displaced person : An interview with William Golding. College English. Vol. XXVI. March. 1965. P. 480-482.

7. Кечерукова М. Символика и проблематика романа-притчи Уильяма Голдинга «Наследники». Омский научный вестник. 2006. № 9. С. 262-265.

8. Гринько О. Функціонування символів у романі В. Голдінга «Спадкоємці». Наукові записки Кіровоградського державного педагогічного університету імені Володимира Винниченка. Серія «Філологічні науки». 2009. Вип. 81 (2). С. 162-165. URL: http://nbuv.gov.ua/UJRN/ Nzs_2009_81\%282\%29_42 (дата звернення: 12.04.2021)

9. Oldsey B., Weintraub S. The Art of William Golding. New York : Harcourt, 1965. 271 p.

10. Шаповал О. Притча в художній структурі ранніх романів В. Голдінга. Жанри $і$ жанрові проиеси в історико-культурній перспективі : колективна монографія / заг. ред. О. Кеба. Кам'янецьПодільський : Аксіома, 2012. С. 198-223.

11. Golding W. The Inheritors. London : Faber \& Faber, 2005. 240 p.

12. Нямцу А., Литвинюк О. Міфопоетика Вільяма Голдінга : монографія. Чернівці : Чернівецький нац. ун-т, 2011. 232 с.

13. Тресиддер Дж. Словарь символов. Пер. с англ. С. Палько. Москва : Фаир-Пресс, 1999. 448 с.

14. Мифы народов мира : энциклопедия : в 2-х т. / гл. ред. С. Токарев. Москва : Советская энциклопедия, 1980. Т. $1:$ А - К. 672 с.

15. Redpath Ph. William Golding : A Structural Reading of his Fiction. London; New York : Totowa ; Vision ; Barnes \& Noble, 1986. 222 p.

16. Ахундов М. Концепции пространства и времени : истоки, эволюция, перспективы. Москва : Наука, 1982. $224 \mathrm{c}$.

17. Johnston A. Of Earth and Darkness : The Novels of William Golding. Columbia, Mo. ; London : University of Missouri Press, 1980. 312 p.

\section{REFERENCES}

1. Averintsev, S.S. (1971) Simvol [Symbol]. Kratkaya literaturnaya entsiklopediya - Short literary encyclopedia (Vol. 1-9) A.A. Surkov (ed.). M. : Sovetskaya entsiklopediya, Vol. 6 : Priskazka "Sovetskaya Rossiya", 826-831 [in Russian].

2. Pavlychko, S.D. (1993) Wiliam Golding i kryza ratsionalizmu [William Golding and the crisis of rationalism]. Labirynty myslennia. Intelektualnyi roman suchasnoi Velykobrytanii-Labyrinths of thinking. An intellectual novel of modern Great Britain (pp. 40-58). K. : Naukova dumka [in Ukrainian].

3. Shapoval, O.H. (2005) Motyv vohniu v romani V. Goldinga "Volodar much" [The motif of fire in W. Golding's "Lord of the Flies"]. Naukovi pratsi Kamianets-Podilskoho derzhavnoho universytetu. Filolohichni nauky - Scientific works of Kamyanets-Podilsky State University. Philological sciences. 10 (2), 138-143 [in Ukrainian].

4. Miroshnychenko, L.Ya. (2011) Heraklitovyi vohon u romani V. Goldinga "Vydyma temriava" [Heraclitus Fire in W. Golding's "Darkness Visible"]. Movni i kontseptualni kartyny svitu : zb. nauk. prats - Linguistic and conceptual pictures of the world : collection of scientific works. 39, 80-87 [in Ukrainian].

5. Grynko, O.S. (2014) Kontsepty-arhetypy v prozi V. Goldinga [Archetypal concepts in W. Golding's prose fiction] (PhD Thesis) : 10.02.04. Odesa: Odesa I. Mechnikov National University, 20 p.

6. Dick, B.F. (1965) The novelist is a displaced person: An interview with William Golding. College English. 26 (3), 480-482.

7. Kecherukova, M.A. (2006) Symvolika i problematika romana-pritchi U. Goldinga "Nasledniki" [Symbols and problems in the W. Golding's "The Inheritors"]. Omskiy nauchnyi vestnik-Omsk Scientific Bulletin. 9, 262-265 [in Russian].

8. Hrynko, O.S. (2009) Funktsionuvannia symvoliv v romani V. Goldinga "Spadkoiemtsi" [Functions of the symbols in the W. Golding's "The Inheritors"]. Naukovi zapysky Kirovohradskoho derzhavnoho 
pedahohichnoho universytetu imeni V. Vinnychenko. Ser. : Fililohochni Nauky - Scientific notes of Kirovograd State Pedagogical University named after V. Vynnychenko: Filological Sciences. 81 (2). 162-165. [in Ukrainian].

9. Oldsey, B.S., Weintraub, S. (1965) The Art of William Golding. N. Y. : Harcourt.

10. Shapoval, O.H. (2012) Prytcha v khudozhnii strukturi rannikh romaniv V. Goldinga [A fable in the artistic structure of W. Golding's early novels]. Zhanry $i$ zhanrovi protsesy $v$ istoryko-kulturnii perspektyvi Genres and genre processes in historical and cultural perspective : kolektyvna monohrafiia. O.V. Keba (ed.). (pp. 198-223) Kamianets-Podilskii : Aksioma [in Ukrainian].

11. Golding, W. (2005) The Inheritors. L. : Faber \& Faber.

12. Niamtsu, A.Ye., Lynvyniuk, O.M. (2011) Mifopoetyka Viliiama Goldinga [Mythopoetics of William Golding]. Chernivtsi : Chernivetskii National University [in Ukrainian].

13. Tresidder, Dzh. (1999) Slovar simvolov [Dictionary of Symbols] M. : Fair-Press [in Russian].

14. Tokarev, S.A. (Ed). (1980) Mify narodov mira : entsiklopediya [Myths of the peoples of the world: encyclopedia] (Vol. 1-2) M. : Sovetskaya Entsiklopediya [in Russian].

15. Redpath, Ph. (1986) William Golding: A Structural Reading of his Fiction. L ; Totowa (N. J.) : Vision : Barnes \& Noble.

16. Ahundov, M.D. (1982) Kontseptsii prostranstva i vremeni: istoki, evolyutsiya, perspektivyi [Concepts of space and time: origins, evolution, perspectives]. M. : Nauka [in Russian].

17. Johnston, A. (1980) Of Earth and Darkness: The Novels of William Golding. Columbia, Mo.; L. : University of Missouri Press. 